\title{
Description of Colonoscopy and Histopathology of Chronic Diarrhea Causes in Non-Neoplasm: Literature Review
}

\author{
Afifah Sakdyyah*, M Begawan Bestari**, Sri Suryanti*** \\ *Faculty of Medicine, Universitas Padjadjaran/Hasan Sadikin General Hospital, Bandung \\ ${ }^{* *}$ Division of Gatroentero-hepatology, Department of Internal medicine, Faculty of Medicine, \\ Universitas Padjadjaran/Hasan Sadikin General Hospital, Bandung \\ ***Department of Clinical Pathology, Faculty of Medicine, Universitas \\ Padjadjaran/Hasan Sadikin General Hospital, Bandung
}

\begin{abstract}
Corresponding author:
Afifah Sakdyyah. Faculty of Medicine, Universitas Padjadjaran/Dr. Hasan Sadikin Hospital. Jl. Pasteur No. 38 Bandung Indonesia. Phone: +62-22-2038986; facsimile: +62-22-2040151.E-mail: Afifahsakdyyah@gmail.com
\end{abstract}

\begin{abstract}
Chronic diarrhea is a diarrhea symptom which persists for $\geq 4$ weeks as a symptom of a disease. Chronic diarrhea is a symptom that often becomes the patient's main reason for referral to gastroenterologist. In general, the prevalence of chronic diarrhea is estimated to be $5 \%$ in each population, but there are obstacles in diagnosing the cause of chronic diarrhea. This is due to many differential diagnoses as the cause of chronic diarrhea. The aetiology of chronic diarrhea could be neoplasm and non-neoplasm. In several studies, through results of colonoscopy and histopathology, it was found that the most common cause of chronic diarrhea was nonneoplasm, including inflammatory bowel disease (IBD), microscopic colitis as a risk factor, and infectious colitis as a differential diagnosis. Each of those diseases has similar symptoms, but different pathological description.

Through descriptions of colonoscopy and histopathology of chronic diarrhea causes, it is possible to differentiate each non-neoplasm causes of chronic diarrhea. It could facilitate in differentiating the causes of chronic diarrhea especially in non-neoplasm cases, therefore possibly establishing a definite diagnosis.
\end{abstract}

Keywords: chronic diarrhea, colonoscopy, histopathology, inflammatory bowel disease (IBD), microscopic colitis, infectious colitis.

\section{ABSTRACT}

Diare kronik adalah gejala diare yang berlangsung $\geq 4$ minggu yang merupakan suatu gejala dari penyakit. Diare kronik menjadi suatu gejala yang sering menjadi alasan pasien ke gastroenterologi. Secara umum prevalensi diare kronik sekitar 5\% pada setiap populasi, namun memiliki kendala dalam mendiagnosis penyebab diare kronik. Hal ini disebabkan banyaknya diagnosis banding penyebab diare kronik. Penyebab diare kronik dapat berupa neoplasma dan non-neoplasma. Dalam beberapa penelitian, melalui hasil gambaran kolonoskopi dan histopatologi didapatkan penyebab diare kronik terbanyak adalah non neoplasma, yaitu inflammatory bowel disease (IBD), Microscopic colitis sebagai salah satu factor risiko IBD dan infectious colitis sebagai diagnosis banding IBD. Masing-masing penyakit tersebut memiliki gejala yang mirip, namun gambaran patologi yang berbeda.

Melalui gambaran kolonoskopi dan histopatologi penyebab diare kronik dapat membedakan setiap penyebab diare kronik pada non neoplasm. Hal tersebut memudahkan dalam melihat perbedaan antara penyebab diare kronik terutama pada non neoplasm, sehingga dapat menegakkan diagnosis pasti.

Kata kunci: chronic diarrhea, colonoscopy, histopatology, inflammatory bowel disease (IBD), microscopic colitis, infectious colitis 


\section{INTRODUCTION}

Chronic diarrhea is the condition of faeces with watery consistency and frequency of $\geq 3$ times within 24 hours with weight of faeces $>200 \mathrm{~g} / 24$ hours, which could persist up to $\geq 4$ weeks. ${ }^{1,2,3}$ Chronic diarrhea is a general symptom that may occur in several diseases and becomes one of the most common causes of referral to the gastroenterology clinic. Chronic diarrhea affects approximately $5 \%$ of each population in a certain span of time and around $7-14 \%$ in elderly populations. ${ }^{1,2,4}$

The causes of chronic diarrhea are quite diverse and are not always caused by intestinal disorders. The causes could be neoplasm or non-neoplasm. The most common cause of chronic diarrhea is inflammatory bowel disease (IBD) including ulcerative colitis (UC) and Crohn's disease (CD). Moreover, it could be caused by microscopic colitis, colorectal cancer, maldigestion, influence of certain drugs, and infectious colitis. ${ }^{1,2,5,6}$ Those causes are difficult to differentiate as they exhibited similar symptoms. Therefore it becomes an obstacle in diagnosing the cause of chronic diarrhea.

Procedures of colonoscopy and biopsy are needed to assist in providing a definitive diagnosis as the cause of chronic diarrhea. In a study, procedures of colonoscopy and biopsy could lead to a definitive diagnosis of chronic diarrhea in approximately $15-31 \%$ of cases. The most common diagnoses are non-neoplasms such as IBD, microscopic colitis as a risk factor for IBD, and infectious colitis as a differential diagnosis of IBD. ${ }^{1,2}$ Since non-neoplasm causes of chronic diarrhea are affected by several diseases with similar symptoms, this review discusses the description of colonoscopy and histopathology of non-neoplasm causes of chronic diarrhea.

\section{INFLAMMATORY BOWEL DISEASE (IBD)}

Inflammatory bowel disease (IBD) is a disease with mucosal immune activation, resulting in continuous chronic intestinal inflammation. ${ }^{7}$ IBD is a global disease and health problem throughout the world since the beginning of the $21^{\text {st }}$ century. ${ }^{7,8,9}$

The type of IBD can be seen from the difference in colonoscopy and histopathological features. Using colonoscopy, we can identify the involved segment, from the terminal ileum to the rectum. In histopathology examination, it is possible to compare the normal and the abnormal tissue, to help determining the degree of histological changes in the patient. ${ }^{9}$ In such examination, there are 2 main types of IBD, namely ulcerative colitis and Crohn's disease, with histopathologic results as follows: architectural abnormalities including crypt branching/shortening, decreased crypt density, and irregular mucosal surface and inflammatory feature including transmucosal increase of lamina propria mononuclear cells, and the presence of epithelioid granulomas. ${ }^{10}$

\section{Ulcerative Colitis}

Ulcerative colitis is a chronic inflammatory disease of the intestines which could involve the rectum and continuous to spread proximally. The main symptoms are bloody diarrhea, abdominal pains, faecal urgency, and tenesmus. ${ }^{11,12}$

Based on the Montreal classification, lesion locations in ulcerative colitis are classified into proctitis (lesion limited to the rectum), left-sided (lesion limited to the distal colonic mucosa to the splenic flexure), and extensive (limited proximal to the splenic flexure). ${ }^{13}$ According to several studies, based on lesion locations according to the Montreal classifications, proctitis (lesion limited to the rectum) was dominantly found. ${ }^{9,11,14,15,16}$ However, in some cases it can spread proximal colon, sometimes involving the entire colon (pancolitis). ${ }^{9,17}$

Lesion which could be identified in colonoscopy descriptions of ulcerative colitis can be identified based on the severity of the disease. ${ }^{18}$ In the acute phase, the lesions were identified due to the signs of inflammation, such as erythema of the mucosa, irregular vascular pattern, oedema, and erosion or even ulceration of the mucosa with irregular size. ${ }^{9,13,14,19}$ In addition, there are reddish bumps called pseudopolypes with small and variation shapes. ${ }^{19}$ In the advanced stage, the colon become narrowed and shortened, and stenosis occurs. In the recovery stage, there are usually no ulcers, mucosal atrophy, and in some cases the mucosa is normal..$^{13,18}$

Furthermore, in the appearance of abnormal lesions, tissues were taken for biopsy with the aim to identify the histopathology of the lesions. In the acute phase, there is an increase in inflammatory cells, such as infiltration of neutrophil and eosinophils in the lamina propria, basal plasmocytosis and basal lymphoid aggregates, as well as the accumulation of neutrophils in the crypt which forms crypt abscess. ${ }^{19,20}$ The progressive damage to the crypt causes changes in crypt form, such as crypt atrophy, crypt branching, crypt shortening, and crypt distortion. ${ }^{9,11,14,19,21}$ There could be diffused damages to the mucosa, such as abnormal epithelial cells, mucin depletion, and Paneth cell metaplasia, which is an indication of chronic colitis. In the recovery stage, usually there is the presence of normal mucosa with increased mucin. However, there is still an abnormal 
gland with irregular shape, gap between the crypt and the muscularis mucosa, Paneth cell metaplasia. ${ }^{15,18}$

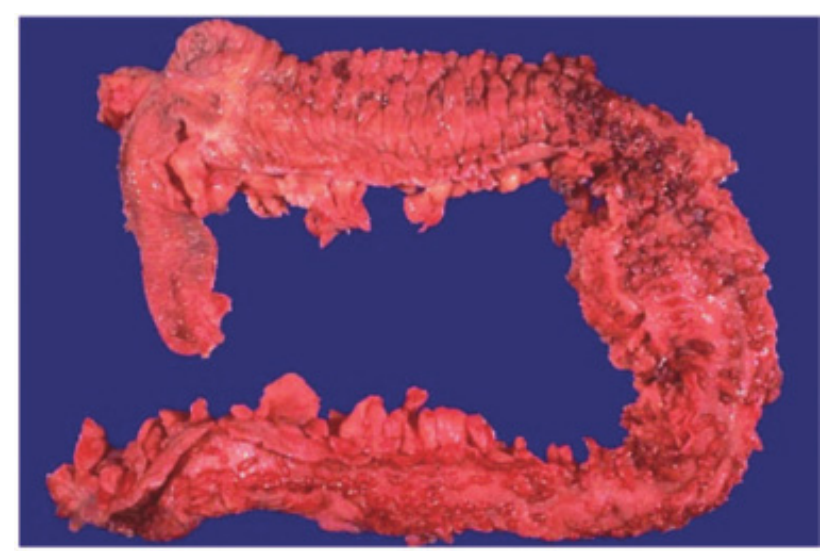

Figure 1. Macroscopic features of ulcerative colitis. Diffuse erythema, edema, and many inflammatory polyps are noted in the rectum, left colon, transverse colon, and hepatic flexure. ${ }^{22}$
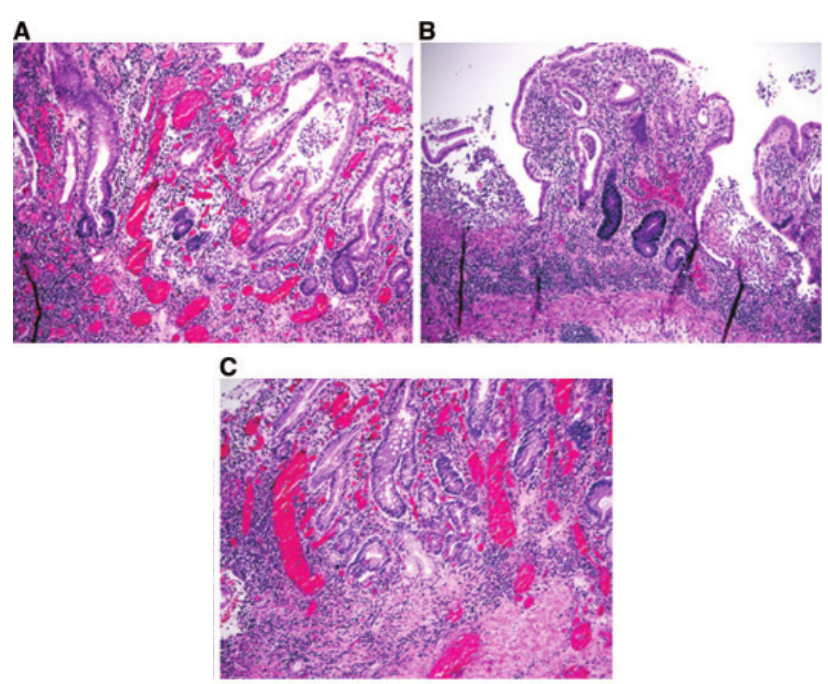

Figure 2. Microscopic featues of ulcerative colitis. A and B: architectural distortion, including shortening of crypts, variation in the sizes and shapes of crypts, and basal lymphoplasmacytosis. C: paneth cell metaplasia and pyloric gland metaplasia in the left colon ${ }^{22}$

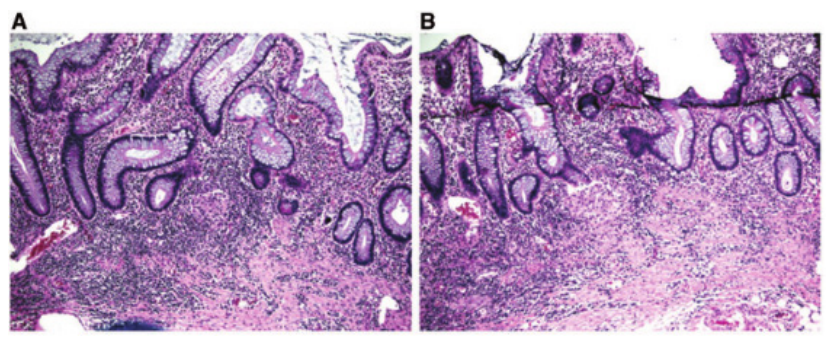

Figure 3. A. proximity of histiocytes near a crypt. B: association of histiocytes with damaged crypts on deeper levels ${ }^{22}$

\section{Crohn's Disease}

Crohn's disease is a chronic inflammation of the digestive tract, from the mouth to the anus, most commonly found in the ileum and colon. ${ }^{7,9,23}$ The main symptoms in Crohn's disease are abdominal pain, watery diarrhea, and weight loss. ${ }^{9}$
Based on the Montreal classification, lesions in Crohn's disease are divided into L1 (ileal), L2 (colonic), L3 (ileocolonic), and L4 (upper GI). ${ }^{13}$ According to several studies, based on the Montreal classification, lesions were dominantly found in the ileocolonic segment. ${ }^{9,15,24,25,26,27}$ Additionally, Crohn's disease lesions are often found on the right side of the colon and is extremely rare in the rectum. The distribution of the lesion is spread to certain segments only, rarely completely. ${ }^{26,28}$

Lesions which could be identified in colonoscopy descriptions of Crohn's disease were signs of inflammation and distributions per segments, rarely found thoroughly. The forms of the lesion that can be found as signs inflammation include irregular vascular pattern, erythema, erosion or even ulceration, called aphthous ulcer, which then enlarges and deepens, then forming edema. ${ }^{15,21,25} \mathrm{In}$ the healing stage, there is the formation of scars which causes strictures, friability, and presence of cobblestoning. ${ }^{9,28,29}$ Lesions which are characteristics of Crohn's disease are aphthous ulcer and cobblestoning (an area a like to a round stone due to presence of longitudinal and circular gap along with ulcer which separates mucosal surface) ${ }^{9,24}$

Furthermore, histopathological examination in Crohn's disease showed crypt abnormalities such as focal crypt atrophy and distortion, and villous atrophy. ${ }^{15,21}$ Additionally, there were also inflammatory cells infiltration such as epithelial cell non caseating granuloma, focal inflammation in lamina propria, focal cryptitis, focal crypt abscess, eosinophil infiltrate in mucosal layer, lymphoplasmocytic infiltrate in submucosal layer, and lymphoplasmocytic infiltrate in

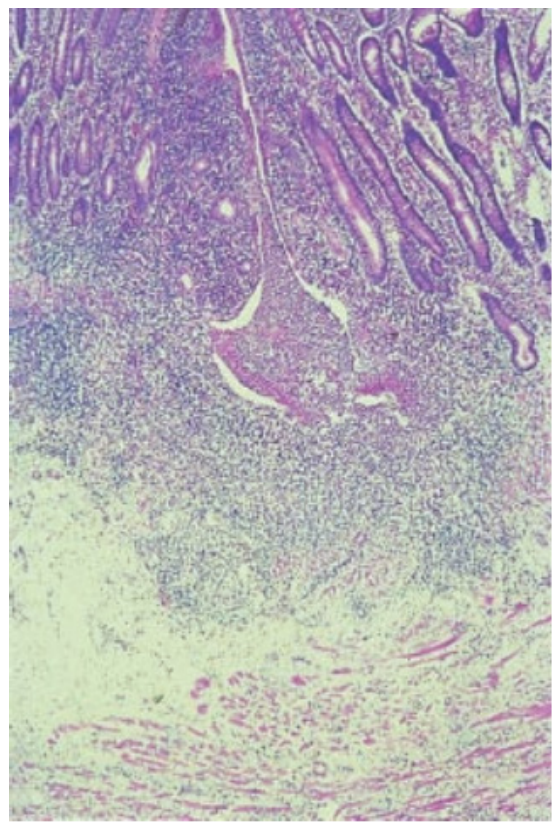

Figure 4. Crohn's disease. Aphthoid ulcer In the ileum: early mucosal ulcer, centrally located and appearing as a mountain top ulcer ${ }^{31}$ 
muscular layer. ${ }^{25,30}$ Complications in Crohn's disease can include carcinoma of the colon, but the incidence is lower than that of ulcerative colitis. Characteristics found are mucosal changes, such as Paneth cell metaplasia and neural cell hyperplasia., ${ }^{9,26}$

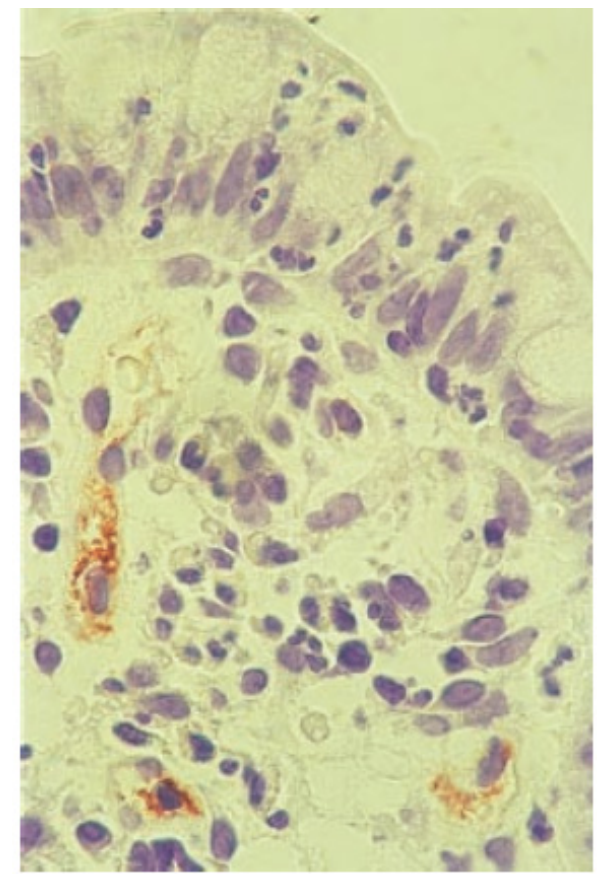

Figure 5. Early mucosal lesion in Crohn's disease (CD) be associated with damage of small capillaries ${ }^{31}$

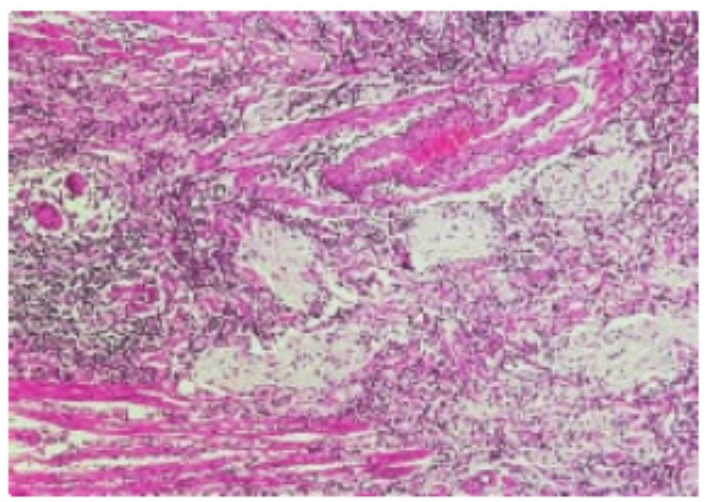

Figure 6. Crohn's disease is characterized by the presence of granulomas and by hyperplasia of the submucosal nerves, sometimes called neuromatous lesion. ${ }^{31}$

\section{MICROSCOPIC COLITIS}

Microscopic colitis is an idiopathic disease with chronic diarrhea, not bloody nor watery, without weight loss, despite the presence of abnormality on endosocopy. ${ }^{32,33,34,35}$ Microscopic colitis is divided into 2 types: collagenous colitis (CC) and lymphocytic colitis (LC) with the same clinical symptoms, but differences in the histopathology descriptions. Histopathological descriptions are required to determine the diagnosis by procedures of endoscopy. ${ }^{32,33}$ In several studies, it was found that the occurrence of Lymphocytic Colitis is more common than Collagenous Colitis..$^{32,34,36}$
Colonoscopic descriptions in microscopic colitis could be found in the terminal ileum, right side colon, left side colon, and some in the rectum. ${ }^{32,37,38}$ Lesion in the right colon is mostly found in collagenous colitis, while lesion in the left colon, mostly found in lymphocytic colitis. ${ }^{34,33}$ In those areas, there were several lesions identified such as normal mucosa and abnormal mucosa. In the abnormal mucosa, there could be found inflammation signs such as erythema, irregular vascular pattern, presence of oedema, formation of linear ulceration, a bit of mucosal laceration and mucosal nodularity. ${ }^{34,32,39,40}$

Furthermore, histopathology identification was conducted on microscopic colitis to differentiate each types of microscopic colitis. In lymphocytic colitis, the following were found: increased surface intraepithelial lymphocytes $>20$ per 100 epithelial cell, increased inflammation in lamina propria, and flat surface epithelial damage, mucin depletion, and vacuolization, and absence of collagen thickening in the subepithelial or slightly thickened subepithelial collagen. . $3,37,38,39,40^{-1}$ Meanwhile, in collagenous colitis, the following were found: thickened subepithelial collagen band $>10 \mu \mathrm{m}$, increased inflammation in lamina propria, subepithelial surface, and epithelial surface damage nearly the same as lymphocytic colitis. ${ }^{33,34,38,39}$

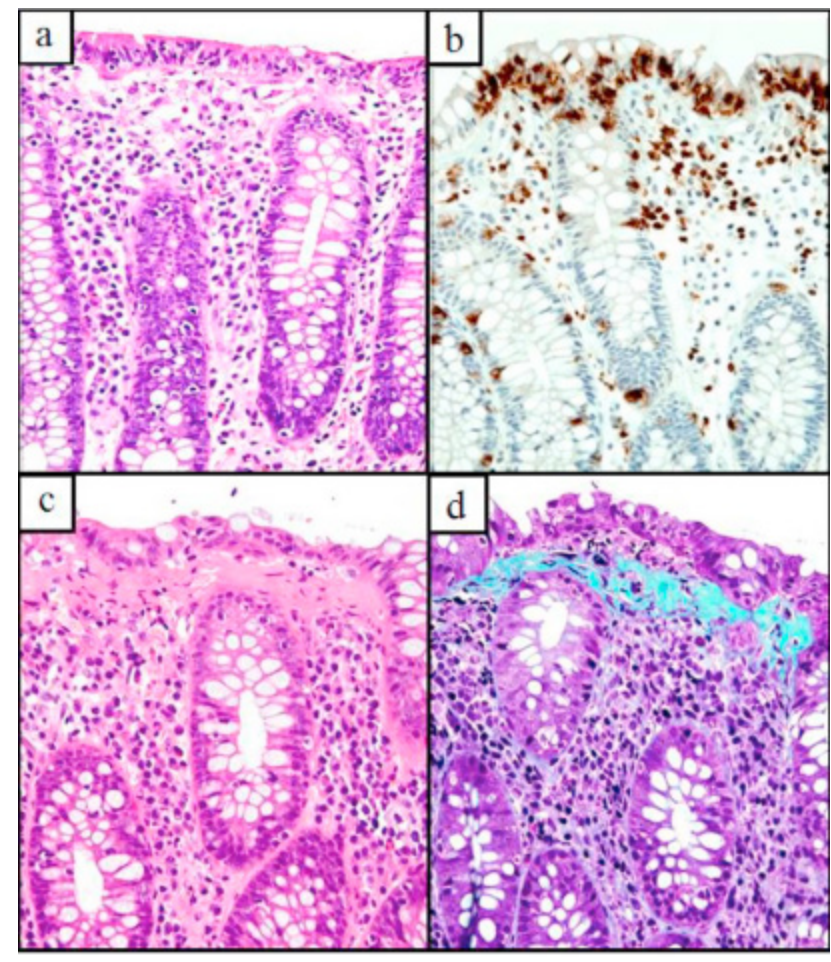

Figure 7. Histology of lymphocytic colitis and collagenous colitis. A: lymphocytic colitis; haematoxylin and eosin. B: lymphocytic colitis; CD3. C: collagenous colitis; haematoxylin and eosin. D: collagenous colitis, Masson's trichrome ${ }^{38}$ 
Another type of microscopic colitis is incomplete microscopic colitis. Incomplete microscopic colitis has similar clinical symptoms to microscopic colitis but does not meet the criteria of CC nor LC based on histopathology descriptions. Histopathology found in incomplete lymphocytic colitis were increased intraepithelial surface lymphocytes with $>10$ to $\leq 20$ per 100 epithelial cells. Furthermore, histopathology in incomplete collagenous colitis were thickened subepithelial collagenous band $>5$ to $\leq 10 \mu \mathrm{m} \cdot{ }^{34,38,39,40}$

\section{INFECTIOUS COLITIS}

Infectious colitis is a diarrhea symptom found with inflammation in the colon seen by visualization, by history taking, colonoscopy, with bloody diarrhea or presence of mucus in diarrhea, and examinations of lactoferrin and culture. ${ }^{41}$

Possible causes of infectious colitis include bacterial, viral, or parasite infections. Bacterial causes include Salmonella, Campylobacter jejuni, E.coli, Clostridium difficile, Mycobacterium tuberculosis infections, and so on. Viral causes include Rotavirus, Cytomegalovirus, Adenovirus, and Norovirus. Parasite infection by Entamoeba histolytica. ${ }^{6,41,42}$

In general, lesions of infectious colitis could be found in the terminal ileum, cecum, colon, ileocecal, sigmoid, and rectum. Furthermore, histopathology descriptions in infectious colitis could include focal abnormal architecture, predominantly acute mucosal inflammation, abnormal focal mucosal inflammation, basal plasmacytosis, predominant neutrophil, and pseudomembrane. ${ }^{5,43}$ However, in each causes of infectious colitis, there is a specific pathology.

In Mycobacterium tuberculosis, lesions were often found in the cecum and ileocecal regions. Forms of lesion include transverse ulceration, surrounded by inflammation cells and damaged ileocecal valve., ${ }^{6,44}$ Furthermore, histopathology in Mycobacterium tuberculosis is similar to Crohn's disease, mimicking Crohn's disease, in the form of multiple submucosal inflammation granulomas in the submucosa, consisting of epithelioid histocytes and multinucleated giant cell with central caseation necrosis. .,6,43 $^{5}$

Clostridium difficile has a characteristic histopathology of pseudomembrane. Pseudomembrane is formed due to increased growth in $C$. difficile, resulting in an increase of inflammation cells which causes bacterial death and accumulation of damaged mucosal tissue. ${ }^{5,43,45}$ Pseudomembrane is found mostly on the left sided colon and few cases can be found on the right sided colon. ${ }^{46,47}$

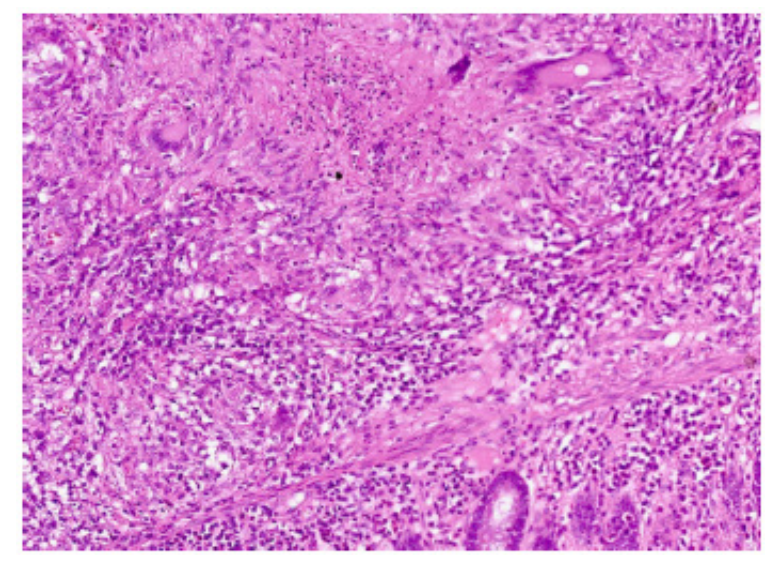

Figure 8. Histology of Mycobacterium tuberculosis showed granulomatous colitis characterised by histiocytes and giant cells with caseous necrosis ${ }^{43}$

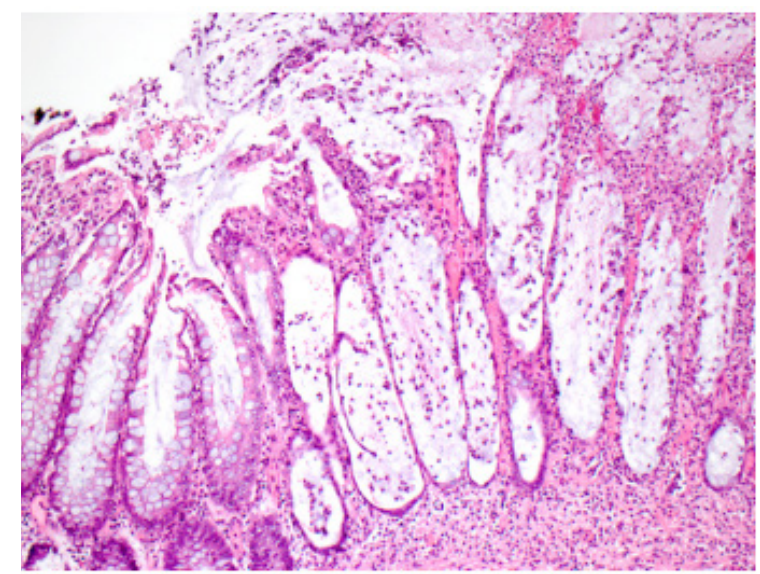

Figure 9. Histology of pesudomembranous (Clostridium difficile) colitis showed a spray of nuclear debris, neutrophils, fibrin and mucin erupting out of the crypts, forming an inflammatory membrane ${ }^{43}$

Yersinia enterocolitica has lesions like oedematous, ulcers with an irregular shape, and with exudates. Lesion is usually found in the terminal ileum and proximal colon. ${ }^{6,44}$ Histopathology examination may reveal the presence of granulomatous inflammation, which contains lots of histiocytes, as well as the presence of hyperplastic Payer's patches. ${ }^{43,47}$

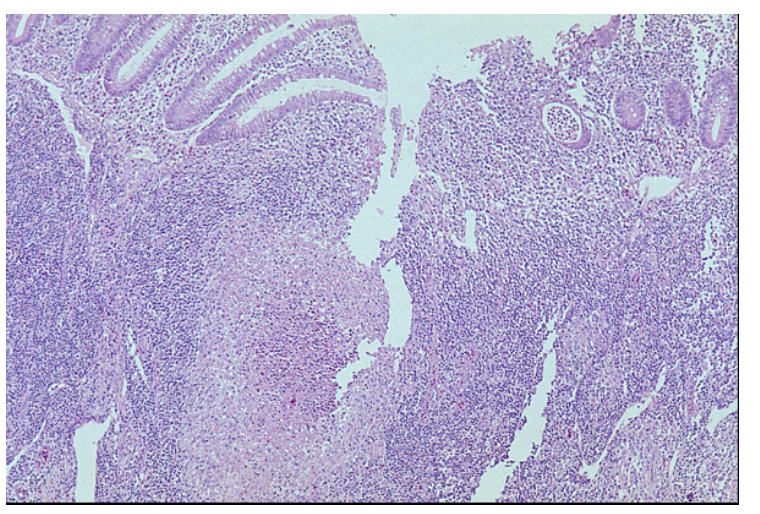

Figure 10. Histology of Yersinia enterocolitica showed granulomas formed in the thickened mucosa showing lymphoid hyperplasia. Courtesy of Pathology outlines 
Cytomegalovirus are single or multiple round lesions that can be found in the caecum and sigmoid. ${ }^{44,48}$ Besides, it can be in the form of erosions, erythema, and inflammatory polyps with predominance of granulation tissue and necrosis. ${ }^{47,48}$ Histopathologic examination of cytomegalovirus is an enlarged intranuclear inclusion body in the host cell nucleus which is noisy like a halo, thus it is shaped like an owl's eye and smaller cytoplasmic inclusions. ${ }^{43}$
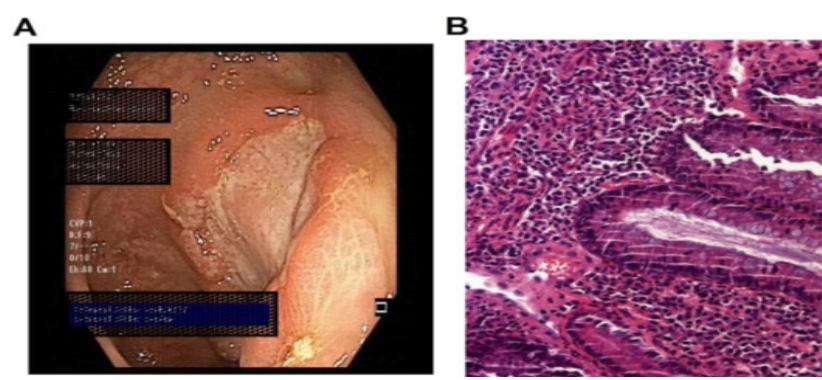

C

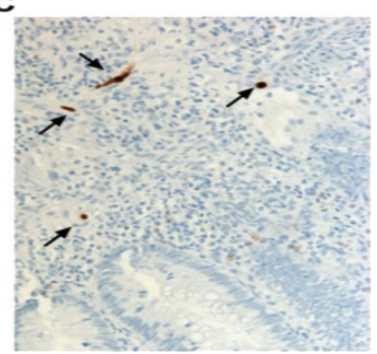

Figure 11. Representive CMV-related findings in a patient with refractory irColitis. A: deeply excavated, large ulceration in the sigmoid observed during colonoscopy. B: histology showed plasma cell-rich inflammation with reactive changes of crypt epithelium ${ }^{48}$

In Entamoeba histolytica infection, there are round or irregularly shaped lesions with exudate and ulceration. Lessions are commonly found in the cecum, right sided colon, sigmoid, and rectum. ${ }^{44}$ Furthermore, histopathology of E. histolytica includes an increase of eosinophil and neutrophils in the lamina propria, and phagocytic red blood cell in the cytoplasm. ${ }^{6,44}$ Later, an inflammatory process occurs and forms exudates and nuclear debris. ${ }^{47}$

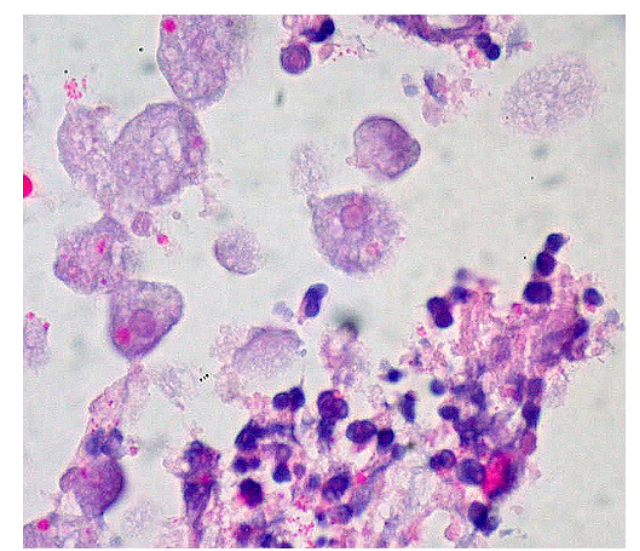

Figure 12. Histology of Entamoeba histolytica. Courtesy of Pathology outlines (http://www.pathologyoutlines.com)

\section{CONCLUSION}

In chronic diarrhea patients, it is necessary to accurately distinguish the cause, because there are many causes of chronic diarrhea with similar symptoms. Differences in chronic diarrhea causes could be identified by descriptions of colonoscopy and histopathology. This is expected to be an accurate tool to differentiate the pathology of each causes of chronic diarrhea.

IBD has symptoms of chronic, bloody diarrhea, characteristic changes of inflammation in the lesion, and presence of architectural changes in the mucosa, lamina propria, and crypts, and increase of inflammation cells in histopathology. Degree of severity, lesion distribution, and description of histopathology are an important frame for differential diagnoses against other diseases, such as erythema, ulceration, erosion, changes of vascularization pattern, damage in mucosal layer, Paneth cell metaplasia, damage in crypt and ileum, colon, and rectal involvement. Those descriptions could differentiate ulcerative colitis and Crohn's disease with each of its characteristic histopathology. Differential diagnoses similar to IBD include prolonged infectious colitis. Colonoscopy descriptions between IBD and infectious colitis, often found such as ulceration, erythema, changes of vascularization pattern, oedema, and similar distributions of lesion, but with differing histopathology between IBD and infectious colitis.

Microscopic colitis is a cause of watery chronic diarrhea without bleeding. There are 2 types of MC: collagenous colitis and lymphocytic colitis. Collagenous colitis and lymphocytic colitis have colonoscopy descriptions with similar lesions and the same distributions, but there are differences in histopathology. Furthermore, there is another variant of microscopic colitis: incomplete microscopic colitis. Symptoms of incomplete microscopic colitis are the same with MC, which includes incomplete collagenous colitis and incomplete lymphocytic colitis. In MC and IMC, there are the same colonoscopic descriptions, but differences in histopathology. Currently, description of colonoscopy and histopathology is a mean to determine a specific diagnosis of the cause of chronic diarrhea.

\section{REFERENCES}

1. Schiller LR, Pardi DS, Sellin JH. Chronic diarrhea: diagnosis and management. Clin Gastroenterol Hepatol 2017;15:182-93.

2. Arasaradnam RP, Brown S, Forbes A, Fox MR, Hungin P, Kelman L, et al. Guidelines for the investigation of chronic diarrhoea in adults: British Society of Gastroenterology, 3rd edition. Gut 2018;67:1380-99. 
3. Kemenkes RI. Buku Saku Petugas Kesehatan Lintas Diare. Dep Kesehat RI, Direktorat Jendral Pengendali Penyakit dan Penyehatan Lingkung. 2011;1-40.

4. Abdullah M, Firmansyah MA. Clinical approach and management of chronic diarrhea. Acta Med Indones 2013;45:157-65.

5. Schiller LR, Pardi DS, Spiller R, Semrad CE, Surawicz CM, Giannella RA, et al. Gastro 2013 APDW / WCOG Shanghai Working Party Report: Chronic diarrhea : Definition, classification, diagnosis. 2014;29:6-25.

6. Kaiser L, Surawicz CM. Infectious causes of chronic diarrhoea. Best Pract Res Clin Gastroenterol 2012;26:563-71.

7. Hanić M, Trbojević-Akmačić I, Lauc G. Inflammatory bowel disease - glycomics perspective. Biochim Biophys Acta - Gen Subj 2019;1863:1595-601.

8. Yamamoto-Furusho JK, Bosques-Padilla FJ, Charúa-Guindic L, Cortés-Espinosa T, Miranda-Cordero RM, Saez A, et al. Inflammatory bowel disease in Mexico: Epidemiology, burden of disease, and treatment trends. Rev Gastroenterol México English Ed 2020;x:x.

9. Flynn S, Eisenstein S. Inflammatory Bowel Disease Presentation and Diagnosis. Surg Clin North Am 2019;99:1051-62.

10. Villanacci V, Antonelli E, Geboes K, Casella G, Bassotti G. Histological healing in inflammatory bowel disease: A still unfulfilled promise. World J Gastroenterol 2013;19:968-78.

11. Feuerstein JD, Moss AC, Farraye FA. Ulcerative Colitis. Mayo Clin Proc 2019;94:1357-73.

12. Lin WC, Chang CW, Chen MJ, Chu CH, Shih SC, Hsu TC, et al. Challenges in the diagnosis of ulcerative colitis with concomitant bacterial infections and chronic infectious colitis. PLoS One 2017;12:6-13.

13. Shergill AK, Lightdale JR, Bruining DH, Acosta RD, Chandrasekhara V, Chathadi K V., et al. The role of endoscopy in inflammatory bowel disease. Gastrointest Endosc 2015;81:1101-1121.e13.

14. Christensen B, Hanauer SB, Gibson PR, Turner JR, Hart J, Rubin DT. Segmental Histological Normalisation Occurs in Ulcerative Colitis but Does Not Improve Clinical Outcomes. J Crohn's Colitis 2020;4:x.

15. Wehkamp J, Götz M, Herrlinger K, Steurer W, Stange EF. inflammatory bowel disease. Dtsch Arztebl Int 2016;113:7281.

16. Steed H. Ulcerative colitis. Med (United Kingdom) 2019;47:371-6.

17. Cushing KC, Tan W, Alpers DH, Deshpande V, Ananthakrishnan AN. Complete histologic normalisation is associated with reduced risk of relapse among patients with ulcerative colitis in complete endoscopic remission. Aliment Pharmacol Ther 2020;51:347-55.

18. john R Goldblum, Laura W. Lamps, Jesse K, McKenney JLM. SURGICAL Pathology. 11th ed. international edition, editor. elsevier; 2011.p.635-50.

19. Gajendran M, Loganathan P, Jimenez G, Catinella AP, Ng N, Umapathy $\mathrm{C}$, et al. A comprehensive review and update on ulcerative colitis,. Disease-a-Month 2019;65:12.

20. Choi EYK, Appelman HD. Chronic Colitis in Biopsy Samples: Is It Inflammatory Bowel Disease or Something Else? Surg Pathol Clin 2017;10:841-61.

21. Langner C. Colorectal Normal Histology and Histopathologic Findings in Patients with Chronic Diarrhea. Gastroenterol Clin North Am 2012;41:561-80.

22. DeRoche TC, Xiao SY, Liu X. Histological evaluation in ulcerative colitis. Gastroenterol Rep 2014;2:178-92.
23. Mak WY, Hart AL, Ng SC. Crohn's disease. Med (United Kingdom) 2019;47:377-87.

24. Gajendran M, Loganathan P, Catinella AP, Hashash JG. A comprehensive review and update on Crohn's disease. Disease-a-Month 2018;64:20-57.

25. Hammoudi N, Cazals-Hatem D, Auzolle C, Gardair C, Ngollo M, Bottois H, et al. Association between microscopic lesions at ileal resection margin and recurrence after surgery in patients with Crohn's Disease. Clin Gastroenterol Hepatol 2020;18:141-9.

26. $\mathrm{Hu}$ AB, Tan W, Deshpande V, Ananthakrishnan AN. Ileal or colonic histologic activity is not associated with clinical relapse in patients with Crohn's Disease in endoscopic remission. Clin Gastroenterol Hepatol 2020;x:x.

27. Löwenberg M, Vermeire S, Mostafavi N, Hoentjen F, Franchimont D, Bossuyt P, et al. Vedolizumab induces endoscopic and histologic remission in patients with Crohn's Disease. Gastroenterology 2019;157:997-1006.

28. Sun XW, Wei J, Yang Z, Jin XX, Wan HJ, Yuan BS, et al. Clinical features and prognosis of Crohn's Disease with upper gastrointestinal tract phenotype in Chinese patients. Dig Dis Sci 2019;64:3291-9.

29. Lewis JD, Rutgeerts P, Feagan BG, D'Haens G, Danese $\mathrm{S}$, Colombel JF, et al. Correlation of stool frequency and abdominal pain measures with simple endoscopic score for Crohn's Disease. Inflamm Bowel Dis 2020;26:304-13.

30. Saade C, Nasr L, Sharara A, Barada K, Soweid A, Murad F, et al. Crohn's disease: A retrospective analysis between computed tomography enterography, colonoscopy, and histopathology. Radiography 2019;25:349-58.

31. Colitis U. Histopathology of Crohn's Disease and ulcerative colitis. Histopathology 2003;18:726-33.

32. Marlicz W, Skonieczna-Żydecka K, Yung DE, Loniewski I, Koulaouzidis A. Endoscopic findings and colonic perforation in microscopic colitis: A systematic review. Dig Liver Dis 2017;49:1073-85.

33. Pardi DS. Diagnosis and management of microscopic colitis. Am J Gastroenterol 2017;112:78-85.

34. Langner C, Aust D, Ensari A, Villanacci V, Becheanu G, Miehlke S, et al. Histology of microscopic colitis-review with a practical approach for pathologists. Histopathology 2015;66:613-26.

35. Kumar aster abbas. basic pathology. tenth edit. viney kumar, abul abas jon aster, eds. Elsevier; 1394;5: 285-99.

36. Fiehn AK, Johan P, Engel H, Lanzarotto F, Goudkade D, Landolfi $\mathrm{S}$, et al. topographical distribution of microscopic colitis and the importance of orientation of paraffin embedded biopsies. 2020;

37. Fu Z, Aldyab M, Arslan ME, Boguniewicz A, Karamchandani $\mathrm{DM}$, Lee H. Lymphocytic colitis pattern of injury presenting as endoscopic polyps: a case series. Hum Pathol 2020;101:10-7.

38. Goudkade D, Fiehn AMK, Landolfi S, Villanacci V, Munck LK, Engel PJH. An investigation of European pathologists' approach to diagnose microscopic colitis. Ann Diagn Pathol 2020;46:151520.

39. Miehlke S, Guagnozzi D, Zabana Y, Tontini GE, Fiehn AMK, Wildt S, et al. European guidelines on microscopic colitis: United European Gastroenterology (UEG) and European Microscopic Colitis Group (EMCG) statements and recommendations. United Eur Gastroenterol J 2020;

40. Tulassay Z, Mihaly E, Herszényi L. Microscopic Colitis: A Challenging Disorder. Dig Dis 2020;38:117-21.

41. Infectious Colitis - StatPearls - NCBI Bookshelf [serial 
online]. [cited 2020 Jul 16]. Available from: https://www. ncbi.nlm.nih.gov/books/NBK544325/

42. Frickenstein AN, Jones MA, Behkam B, McNally LR. Imaging inflammation and infection in the gastrointestinal tract. Int $\mathrm{J}$ Mol Sci 2020;21:x.

43. Moore M, Feakins RM, Lauwers GY. Non-neoplastic colorectal disease biopsies: Evaluation and differential diagnosis. J Clin Pathol. 2020;x:1-10.

44. Nagata N, Shimbo T, Sekine K, Tanaka S, Niikura R, Mezaki $\mathrm{K}$, et al. Combined endoscopy, aspiration, and biopsy analysis for identifying infectious colitis in patients with ileocecal ulcers. Clin Gastroenterol Hepatol 2013;11:673-680.e2.

45. McCollum DL, Rodriguez JM. Detection, Treatment, and Prevention of Clostridium difficile Infection. Clin Gastroenterol Hepatol 2012;10:581-92.

46. Velarde Ruiz-Velasco JA, Aldana-Ledesma JM, Ibarra-Estrada MA, Aguirre Díaz SA, Fernández-Ramírez JA, CárdenasLara F, et al. Clinical and endoscopic features in patients with hospital-acquired diarrhea associated with Clostridium difficile infection. Rev Gastroenterol México (English Ed) 2017;82:301-8.

47. Lamps laura W. surgical pathology of the gasrointestinal system. Vol. 66, springer. london: springer; 2012.p.37-39.

48. Franklin C, Rooms I, Fiedler M, Reis H, Milsch L, Herz $\mathrm{S}$, et al. Cytomegalovirus reactivation in patients with refractory checkpoint inhibitor-induced colitis. Eur J Cancer $2017 ; 86: 248-56$. 